Received 10 February 2020; Accepted 10 March 2020

\title{
Art On My Sleeve: An interview with Steve Averill, graphic designer
}

Russ Bestley, London College of Communication

Steve Averill is a graphic designer, art director, writer and musician. Having been involved in the counter culture in Dublin since the 1960s - including a stint as a DJ in a club called Middle Earth and founding a fanzine called Freep - he gravitated to the emerging punk movement and formed the first Irish punk group, the Radiators From Space (Murphy 2017). He left the band after their first album to concentrate on his design career. Shortly afterwards, he was approached by the bass player of a local band, the Hype, to work on the group's visual identity. The Hype would subsequently become hugely successful after changing their name to U2 at Averill's suggestion.

Having become Creative Director of The Helme Partnership, Averill decided that he wanted to concentrate exclusively on design and set up the consultancy Works Associates. This company evolved through many iterations of location and personnel into AMP Visual where he worked with clients including U2, Elvis Costello, Depeche Mode, the Mavericks and the Script. He continues to perform with Trouble Pilgrims (Murphy 2018), the band that evolved from the Radiators, as well as editing the online Americana fanzine Lonesome Highway.

Russ Bestley (RB): Can you tell us a bit more about your education as a graphic designer and your early career in advertising?

Steve Averill (SA): I was born in 1950, so I was a child of the '60s, coming of age during the era of the Beatles and the beat groups. My first venture into sleeve design was a home-made, cut and paste kind of situation, making my own covers for copies of seven-inch singles that were released in Ireland without picture sleeves. People think it's surprising that from a very young age, when they asked me what I wanted to do I said I wanted to be what was then called a 'commercial artist'. You didn't really have the term graphic designer, it was just commercial artist. When I went along to NCAD (National College of Art and Design) in Dublin to see what was available I was told more or less by the tutor that they only did fine art and sculpture and he was very condescending: they didn't do commercial art.

I left school in 1968 and went to live and work in London. I worked in Boots [high street pharmacy and general store] in Oxford Street which backed onto Carnaby Street, as a temporary manager on the pets and garden counter. Spent my time off going to the Roundhouse and some of the free concerts like the Deviants in Trafalgar Square or visiting record shops and other places like the Indica Bookshop. I was offered a full time position with Boots, but I decided I wanted to return to Dublin to 
pursue a design path. So I worked in London for about three months and then came back to Ireland and got a place in Dun Laoghaire Technical College. They had a one-year basic design course which was the only one I could find in Dublin at the time and it was basic in the extreme. It was interesting though, there were people like Bryan Maguire, the painter and a few people like that who went on to be quite well-known in different disciplines. It taught us a very basic sense of design. From there I went to work in a printing firm which I was told was a career move but in fact was absolutely not a career move, it was an awful job and an awful place to work.

During my time there some friends were doing an evening course at Bolton Street Tech. They told me that once a week they had a tutor who was bit of a weirdo (I think the inference was - like me). They suggested I attend the class even though I was not enrolled. I did for a number of weeks and the tutor, Phil Walsh, became my mentor. He worked at Arks Advertising, one of the most creative advertising agencies in Dublin at the time, as an award-winning art director. He eventually offered me a junior position (earning less money than I was getting in the current job). It was there that I worked alongside Eamonn Carr, Barry Devlin and Charles O'Connor, who all left shortly after to concentrate on their musical careers in the Irish folk-rock band Horslips. That opportunity set me down the path of creativity as I was soon not only working on advertising campaigns but also taking on design projects - logos, letterheads etc - for clients as they came along. One of the agency's main clients was Guinness but there were a host of other ever-changing projects. At the time there were few if any dedicated design consultancies around in Ireland. Kilkenny Design workshop was perhaps the only one, so pure design was a part of our job description.

RB: Can you tell me a little more about the working process at that time?

SA: The overall process was slightly different back then, especially working in an advertising agency. As a junior designer the role was to work closely with your creative group head; each creative group generally consisted of three people. Our role was creative conception which usually meant working with a copywriter, as most of the work was advert-based. You would then produce a mock-up that was presented to the client. If that was passed you would then work with the art department and the in-house typographer. This process involved the production of a layout for positioning the type - the team would work out the placement of each line of type and this was then sent to a typesetting facility who would return a print proof which the art department added to the flat, camera-ready artwork. If a photograph was required for the advert you worked with the in-house photographer or a commissioned freelancer depending on the budget and timescale. When I joined Arks Advertising one of the in-house team was Spud Murphy who left soon after and worked for a period as a staff photographer for the weekly music paper Sounds. I worked on a very wide range of client briefs at this 
time, from beer or ice cream through to department stores. In those days the agency scene included many fledgling musicians in much the same way as the art college scene did in England. Phil Walsh eventually encouraged me to move on and I became a member of the design team at OKB, then Kenny's Advertising before working with a specialist advertising consultancy The Creative Department and finally The Helme Partnership. After that it was a case of concentrating on design with ABA, Four 5 One and AMP Visual.

RB: Even before punk, you were involved in the local scene and were documenting youth culture in Ireland with fanzines.

SA: From the age of twelve, music had also been a passion of mine and I regularly attended gigs by local heroes like Grannies Intentions or Peter Adler and the Next in Line together with visiting bands like the Who and the Edgar Broughton Band. I also made frequent trips to London to see others such as the Pink Fairies and Pretty Things. The first fanzine I did was called Freep, short for Free Press, a large sheet folding into a little pamphlet. I was lucky enough to be able to talk to the people behind ZigZag and Friends (later Frendz) magazine and tell them what I was doing and they gave me permission to use certain pieces of their text, and things like that. I'd been a huge admirer of Pete Frame and what he was doing in ZigZag, so I was trying to do that myself.

I was just trying to find my way. I started moving into areas that were more graphic-aligned than music-aligned, because in those days if you weren't a musician you couldn't get on stage. That was the general drift of things, you had to be a super-musician to play on stage. So I got together with a friend of mine, Tom King who was in Dun Laoghaire college with me for a year, and we started doing light shows, with liquid lights and the whole thing. Again, through ZigZag magazine l'd been in touch with a guy from the UK who did light shows for Hawkwind. I was amazed how incredibly generous he was - he sent me a letter telling me exactly how you do it. Obviously he felt I was in Ireland so it wasn't competition but he told me all the secrets of how you do all the moving colours and the whole thing. I really loved doing that, it was great fun.

I suppose Freep was part of that, I think we did probably six or seven issues. One was about Horslips, one was about Hawkwind because I was really interested in what they were doing. I loved that mixture of crude electronics with what they were playing. From all that I felt there must be a way to get back into making music, because that really was my main ambition. I had this idea that maybe I could become an MC, like in Berlin in the Cabaret, become this front person who drew all the strands together. My over-riding influences were bands like the New York Dolls, Flamin' Groovies, the MC5, the Stooges, Velvet Underground and many more. When we started the Radiators we told people it 
was high energy rock, urban blues is what we called it. The word punk hadn't become a trademark, so when it did break in London and the word punk became a sort of thing, everybody tagged us as a punk band.

\section{Insert Fig.01}

RB: So how did you make the move toward forming a band as well as being involved behind the scenes?

SA: I was also working part time in a branch of Golden Discs record shop in Dublin city centre. I would see someone who I felt might fit the bill and then see what records they looked at while in the shop. If the right choices were made I would ask them if they wanted to join a band. Through this method I met Pete Holidai and Billy Morley who were the initial components of what we called Greta Garbage \& the Trash Cans. In the end nothing came of the band as we were unable to find a rhythm section who understood what we were trying to achieve. In frustration Billy left and we auditioned possible replacements. One of those was Philip Chevron. After a short time we also had Jimmy Crashe on drums and Mark Megaray on bass, completing the line-up. Both were friends of Philip. The Radiators From Space then began in earnest. I also then started to use my design skills to create logos, posters and flyers for the band.

RB: So then you started Raw Power fanzine?

SA: Well Raw Power was an obvious Sniffin' Glue thing. We basically said, there's nobody else writing about the Radiators, let's start our own fanzine and do it. But we tried to draw others in. Issue two has the first interview with the Undertones. Philip had friends in Derry... and the guys who started Heat fanzine were also involved. We put it together as a fanzine and either gave it away or sold it and of course I worked in an advertising agency which had a huge photocopier in the basement so you could run off twenty copies and sell them.

RB: Were there any Irish album designers who inspired you, or were you looking elsewhere?

SA: To a large extent most of the records I was consuming were American or UK-based. The only Irish designer that I was aware of who actually did record sleeves was Jim Fitzpatrick through his connection with Thin Lizzy. I knew his work prior to him being a sleeve designer, I knew him as a poster designer. There were also people doing things I admired, such as Charles O'Connor who was doing the Horslips album designs. His Happy to Meet... Sorry to Part album cover (December 1972) was a magnificent design based on an eight-sided concertina with die cuts in it, a very expensive piece of design to do. 
That was on an independent label, they were their own team. They had more or less formed as a joke band for this TV commercial, Miranda soft drink, and they carried on doing things and then got an Irish TV programme. They had the basis of what they were doing and they were building it up from there.

It always struck me, unless you were in Dublin around the time Horslips took off and released their first record ['Johnny's Wedding', March 1972], nobody as a band had ever thought, or ever used, big advertising hoardings for the release of a single. The first day it was released you walked down the street and suddenly you had six of these 60 " by 40 " posters on a wall, each with an individual member of Horslips on them. The impact was incredible, wow, somebody's actually doing something from a local point of view and doing all they need to do to make themselves stand out. And when they finally released Happy to Meet... I was working in Golden Discs and I have never seen, even with people like U2, a record leave the shop in such quantities. We had boxes under the counter and people coming in every two or three minutes and buying albums.

For an Irish band, for an independent band who'd done everything themselves, that was pretty amazing. They were smart people, because when you've got two top copywriters in your band, a very good graphic designer, smart people like Jim Lockheart, there was an intelligence there that sometimes didn't translate to some of the other bands that you met. When I met U2 they had that same kind of drive and ambition, that we need to push this on and do it intelligently and get to where we need to go.

RB: What was the first record sleeve that you designed?

SA: The first sleeve I did was when I was working in the advertising agency. Somebody with a connection to the agency, I don't remember who, wanted a cover designed for a charity album and I was asked to design it. It was very straightforward but it was interesting for me to take on the role of designer and look at the best way to get it across. It was an album for a choir or whatever. I enjoyed it, but I always wanted to get into the rock and roll side of things. That happened with the Radiators. That was probably the first major move into doing my own stuff, controlling my own look and feel for what I wanted to do.

RB: Why the changes of name for your design work on various album credits?

SA: When I was working in the agency I wasn't supposed to be doing outside or freelance work, so I used a number of pseudonyms such as Art On My Sleeve, Rapid Exteriors (which came from my stage name with the Radiators, Steve Rapid) and RX. 
RB: So how did things take off for the Radiators?

SA: The punk aesthetic that had begun to emerge after we got together dictated a certain look and style. When we had the opportunity to record some demos under the guidance of Horslips' drummer Eamonn Carr, I designed the first single cover and the now well-known zig-zag lettering. They were presented to the Chiswick Records owners who Eamonn knew. The word we received back was they were not overly impressed with the sound of the demos but really liked the single cover. So Chiswick's Roger Armstrong came to Dublin and we re-recorded the debut single, 'Television Screen'. As was in keeping with the time before the Macintosh computer became integral to the design process, everything was hand drawn or lettered and the artwork was stuck down to a base board. Indeed typesetting was expensive too, so when it came to the first album all the lettering was done with Letraset dry transfer lettering.

Insert Fig.02, Fig.03, Fig.04

The Radiators logo was created by firstly drawing a pencil grid to get the zig-zag effect. I drew the outline with a Rapidograph then filled the centre with a brush and ink. The initial idea was to emphasise a 'blitzkrieg' attitude to how we were approaching our music. We also used this symbol as an alternative to the flirtation that punk had with overt Nazi imagery in the early days as a sort of antiestablishment shock tactic. However we very soon realised it was open to misinterpretation and dropped this approach. That logo was initially only used on the single cover. However, Chiswick had made some $t$-shirts and it became an identifiable band identity and has resurfaced on a number of occasions such as the Trouble Pilgrim album in 2006. There was a suggestion that it might have been influenced by Malcom Garrett's great Buzzcocks logo but it was in fact done earlier. The line effect used on the cover and other early band pictures was done with a home-made screen created by placing a sheet of close-lined Letraset onto a sheet of clear cell and then using the Repromaster.

Both sleeve and logo were created on white art boards. The single was $\mathrm{s} / \mathrm{s}$ [designed at actual size for reproduction] and the logo was drawn at around 9" wide and then reduced on the PMT camera. One small detail was that Mark, the bass player, was wearing a swastika t-shirt which they removed (with our blessing), but the printer didn't do a particularly great job of matching the lines. The punk era was a more black and white scenario which often meant adopting a slightly more random, unprofessional approach to the artwork. I designed all the Radiators single covers as well as the TV Tube Heart album cover (1977), using a different front cover image for both the Irish CBS version and the Chiswick release. The photographer was an advertising collaborator, lan Finlay, who later shot the U2 October and War front covers. 
Insert Fig.01

Insert Fig.05, Fig.06

Here's a thing. When I sought advice from my elders and betters in the advertising agency about using an existing photograph or image I was told that if I flipped it over from left to right or cropped or treated it in some way there would be no problem. Something I wouldn't dream of doing now without getting some clearance, but as my superiors had advised me I went ahead and used images in a series of adverts for the Radiators that were just photocopied from magazines. For the second Radiators album Ghostown it was decided to go with a small advert for each track on the album. They ran in all the weekly press at the time; Melody Maker, NME, Sounds and Record Mirror. All the typography was done with Letraset as I couldn't afford typesetting. The only negative response we got was a cease and desist letter from Warner Brothers as I had styled the 'Faithful Departed' advert after the look of the Exorcist. Which was no problem as we only planned to run the series once. But I learned a lesson about copyright!

Insert Fig.07

RB: What can you remember about working with the Virgin Prunes?

SA: It was largely Gavin and Guggi who would be at the forefront of the visual ideas. I was working with the photographer Ursula Steiger and I had these books of natives in Papua New Guinea who painted their faces, and we thought we' $d$ try that for 'Pagan Love Song'. So we did the make-up in that way, simply from having this visual reference. Guggi was also a visual artist and some of the imagery was based around things that he'd drawn or painted. So I worked with him and I always tried to find a graphic style that worked with what he was trying to do.

Insert Fig.08

I kind of watched out for the creative element in the whole thing. I enjoyed it. It was good fun as much as it lasted. I went along to a lot of the Prunes' gigs to see what they were doing. Certainly the thing they did in Trinity College in the library there. That was quite deliberately provoking, probably more punk than a lot of the punk bands who thought they were the epitome of punk in Dublin. It was kind of Dada-esque in many ways. That was sort of the influence. They were deliberately putting values forward and poking various things... the fact that Gavin and Guggi would dress in women's dresses. If you read Kris Needs' book on Suicide, the way he said here was a band that was more punk than most punk bands, the Prunes were similar and they just met a wave of violence, with things thrown at them 
when they supported the Clash. The cartoon vision of punk as four guitars and check pants and roaring became what punk was, but you look and suddenly everyone who was in the first wave had changed dramatically by that stage anyway.

\section{Insert Fig.09}

RB: Your design career, particularly for record sleeves and band identities, took off from this point. Can you talk about your process for designing artwork for other bands?

SA: It was very varied to be honest. Often the critical time for me was to sit down with the artist and talk to them and ask them about the music, what it meant to them, what the songs were about. If I was working with a traditional Irish folk group, I kind of knew exactly where the music was coming from. And in those days genres were very much defined. The genres of country music, jazz, blues or whatever, had certain visual footpaths that you followed for people to understand what you were talking about. Obviously in rock you had crossovers at times.

I tried to understand the act, what they wanted to do, how they wanted to get it across and then I sat down and did very rough sketches of how I thought the direction might go. I was nearly always involved with working with the photographer and choosing the photographer; I worked a lot with Conor Horgan, Amelia Stein and Shane McCarthy. One thing I learned quite early on was never to stick hard and fast to the original concept. We'd come up with as many weird and wacky ideas as we could, and then when we got the results of those, we sat down and looked at them and said 'this really works', 'this didn't work as well as I thought it would' and so on. So you basically have to think on your feet and have an open mind.

There was also a certain amount of respect for me as a person who had a knowledge of music. Certainly in early U2 days I would be pointing them at people like Captain Beefheart saying 'this is something you really should have a listen to, it would work'. And they were incredibly naïve in the early days, the range of what they listened to was quite small, but they were very quick to move into the next phase and really explore the whole world of music that was out there.

Insert Fig.10

RB: So how did the collaboration with U2 come about?

I began working with U2 after meeting Adam Clayton who was in the same year as my younger brother at Mount Temple comprehensive school. Adam mentioned that they wanted to change the band name from the Hype which had negative connotations as well as being the name of one of David 
Bowie's bands. In conversation he suggested something like XTC would be good. So after a week's thought I suggested U2. It was a common expression (you too) but it also related to the Gary Powers spy plane incident, the German U-boat, the name of a popular Ever Ready battery, my Sony U2 tape deck and so on. I was also conscious that it was international and easily rendered graphically. They entered a talent contest in Limerick and won so the name stuck, although Bono didn't like it and wanted to change it. But as with a lot of things it was out there and recognised so, in truth, they really couldn't be anything else now.

Initially I gave them my thoughts and ideas on being in a band and then I created their first poster and single cover. Once the band signed to Island Records there was pressure on them to use the Island art team rather than some unknown Dublin bloke. For that reason some of the early singles were mine and others designed at Island. However, I had requested that they give me the opportunity to design the cover for the debut album, Boy. Once I saw the contact sheet of Peter Rowan taken by Hugo McGuinness (no relation to Paul McGuinness) I immediately knew the image I wanted. I also knew that I wanted it to be as clean as possible and argued for the lack of obvious typography, to just have the band's name buried in the hairline. I felt the image was strong enough to carry the album cover. I was slightly surprised when this went through, though I felt the band's support and endorsement were fundamental to that. It was changed, unbeknownst to me, for the American release because of what they said might be possible accusations of paedophilia-related imagery. In some ways the follow-up, October, had the feel of a first album. It was my intention that it would be a gatefold cover and was designed as such but that option was rejected by the label and so it felt not quite as complete as it should have been. I also initially had a different photograph in mind but was over-ruled. The working relationship with the band was collaborative and they had a respect for my opinion and we often debated what would work best, but it was a positive and rewarding experience for me and probably the one that made my reputation.

RB: How did the design process change through the 1980s and into the 1990s and beyond?

SA: Our design process was unusual in that we all took our design concepts from initial idea through to finished artwork. All this was done, up to the purchase of our first Macintosh computer, on boards with overlays. This meant quite a lot of work with an album like Achtung Baby where so many elements have to match and fit. You didn't get to see the final results in colour until you received a Cromalin print proof back from the printers in order to double check that everything was as you imagined. Not always the case though! 
The longest commitment to a piece of work might be a $\mathrm{U} 2$ album because they might spend anything, in those days up to six, nine months, eighteen months recording an album. So we would go in at the very early part of the process and we would talk to the band in general terms about what they were trying to achieve musically. So, for instance, if you look at the leap between The Joshua Tree and Achtung Baby there was a complete mind-change in their approach to the visuals, the music and everything else. But we would have been involved with listening to the early songs from way, way back before any of this would come along.

\section{Insert Fig.11}

Also titles can affect how you did it. Before we released the Pop album, the artwork on the cover had a different title and different image. We got told very late in the process that the album was going to be called Pop. So we had to rethink our approach to the cover very, very quickly, probably within 48 hours or so to come up with new design. So we just looked at it, myself and my colleague Shaughn McGrath, and thought about how somebody like Lichtenstein would approach pop art now if he had a computer, rather than painting the whole thing. But that was a very quick change in the brief. Likewise, when it came to How to Dismantle an Atomic Bomb, the record label said: 'look, this is a very dangerous title, we don't like it'. But the band had the right to go with it. 'But if anything happens in the world within a few days, or a few weeks before the release, that relates to any type of a bomb attack, we'll have to change the title completely'. So we had to work out a back-up plan that would be there in case anything happened and we had to change everything at the last minute.

RB: What are your visual influences as a designer?

SA: My Influences would originally have come from 'pop' culture in the main; posters, films, book covers, record covers, pulp fiction books, counter-culture magazines and so on. I just love the application of 'art' to commerce. There were some other things such as some old typography books, as the standard fonts available in Dublin were fairly straightforward. I loved the work of the San Francisco poster artists especially Rick Griffin and Stanley Mouse. In the late 1960s and 1970s I became aware of the work of Barney Bubbles and I loved what he did. All these were multi-disciplinary craftsmen. Photography was a massive influence too. Some of the great images that emerged from the likes of David Bailey and Helmut Newton in the fashion world as well as many of the contemporary documentary photographers. I liked collage artists like Kurt Schwitters and John Heartfield and the symbolist movement as well as aspects of Celtic design. I was open to anything and still am to a large degree. Through not going to art college I had to seek these things out as best I could, but now you can find it at your fingertips. Outside of the work with U2, the Virgin Prunes and a couple of other 
bands there was always the overlooking presence of a manager, record company executive or PR person who felt that they had to have their say and that led to more than one compromised design. Overall however I loved the process and challenge.

RB: How has the music graphics profession changed over the last forty years?

The change from vinyl to $C D$ had a major effect on most of us working in that arena. But I never loved one over the other in pure design terms. There are some great CD designs out there and some very basic vinyl record covers. That and the fact that as the Macintosh became omnipresent so the imagination of artists became narrowed. There was a time the roughest of ideas would be passed by a client, but in later times everything had to be exactly as it should be. I loved the occasional mistake that made a project better: that realisation when seeing the first results that the initial idea was crap but that something else created along the way has some magic to it.

\section{Acknowledgements}

Thanks to Steve Averill for an extended email exchange between January and March 2020. This article also draws upon unpublished interviews conducted by Michael Mary Murphy on 7 May 2017 and 27 November 2018 and I am indebted to Michael for generously sharing the draft transcripts.

\section{References}

Bestley, Russ (forthcoming), 'Kicks in style: A punk design aesthetic', Oxford Companion to Punk, Oxford: Oxford University Press.

(2018), 'Design it yourself? Punk's division of labour', Punk \& Post Punk, 7:1, pp. 7-24.

Horslips (1972), 'Johnny's Wedding', 7" single, Dublin: Oats Records.

Horslips (1972), Happy to Meet... Sorry to Part, vinyl album, Dublin: Oats Records.

Murphy, Michael M. (2015), 'Punk and religion in the Republic of Ireland, 1977-1981', Punk \& PostPunk, 4:1, pp. 53-70.

(2017), 'Ireland's First Punk Band': An interview with Radiators From Space', Punk \& Post-

Punk, 6:3, pp. 423-430.

(2018), 'Dark Shadows and Rust: An interview with Trouble Pilgrims', Punk \& Post-Punk, 7:2,

pp. 259-270.

The Radiators From Space (1977), Television Screen, 7" single, London: Chiswick Records.

The Radiators From Space (1977), TV Tube Heart, vinyl album, London: Chiswick Records.

The Radiators (1979), Ghostown, vinyl album, London: Chiswick Records. 
U2 (1980), Boy, vinyl album, London: Island Records.

U2 (1981), October, vinyl album, London: Island Records.

U2 (1983), War, vinyl album, London: Island Records.

U2 (1987), The Joshua Tree, vinyl album, London: Island Records.

U2 (1991), Achtung Baby, CD album, London: Island Records.

U2 (1993), Zooropa, CD album, London: Island Records.

U2 (1997), Pop, CD album, London: Island Records.

U2 (2004), How to Dismantle an Atomic Bomb, CD album, London: Island Records.

Virgin Prunes (1980), Twenty Tens, EP, Dublin: Baby Records.

Virgin Prunes (1982), 'Pagan Love Song', 7” single, London: Rough Trade.

\section{Contact:}

E-mail: r.bestley@lcc.arts.ac.uk

ORCID Number: 0000-0002-5262-219X 